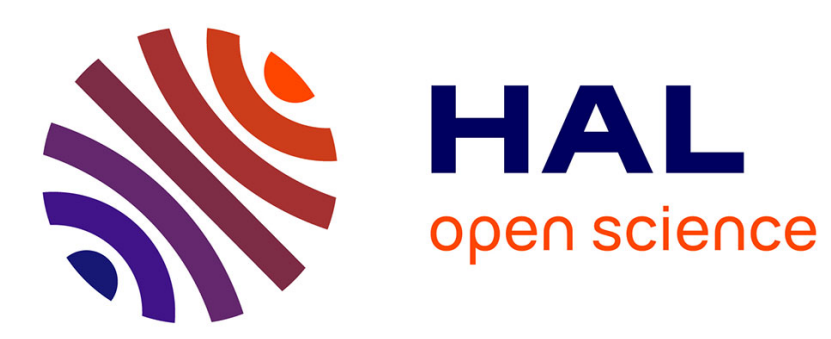

\title{
AC Dielectric Strength of Mineral Oil-Based Fe3O4 and Al2O3 Nanofluids
}

\author{
Usama Khaled, Abderrahmane Beroual
}

\section{To cite this version:}

Usama Khaled, Abderrahmane Beroual. AC Dielectric Strength of Mineral Oil-Based Fe3O4 and Al2O3 Nanofluids. Energies, 2018, 11 (12), pp.3505. 10.3390/en11123505 . hal-02127881

\section{HAL Id: hal-02127881 \\ https://hal.science/hal-02127881}

Submitted on 5 Jun 2019

HAL is a multi-disciplinary open access archive for the deposit and dissemination of scientific research documents, whether they are published or not. The documents may come from teaching and research institutions in France or abroad, or from public or private research centers.
L'archive ouverte pluridisciplinaire HAL, est destinée au dépôt et à la diffusion de documents scientifiques de niveau recherche, publiés ou non, émanant des établissements d'enseignement et de recherche français ou étrangers, des laboratoires publics ou privés. 
Article

\title{
AC Dielectric Strength of Mineral Oil-Based $\mathrm{Fe}_{3} \mathrm{O}_{4}$ and $\mathrm{Al}_{2} \mathrm{O}_{3}$ Nanofluids
}

\author{
Usama Khaled 1,2,*(D) and Abderrahmane Beroual ${ }^{3}(\mathbb{D}$ \\ 1 Department of Electrical Engineering, College of Engineering, King Saud University, P.O. Box 800, \\ Riyadh 11421, Saudi Arabia \\ 2 Department of Electrical Engineering, Faculty of Energy Engineering, Aswan University, \\ Aswan 81528, Egypt \\ 3 Ecole Centrale de Lyon, Ampere CNRS UMR 5005, University of Lyon, 36 Avenue Guy Collongue, \\ 69134 Ecully, France; Abderrahmane.Beroual@ec-lyon.fr \\ * Correspondence: ukhaled@ksu.edu.sa; Tel.: +966-56-181-0835
}

Received: 27 November 2018; Accepted: 13 December 2018; Published: 15 December 2018

\begin{abstract}
This paper deals with an experimental study of the influence of conductive $\left(\mathrm{Fe}_{3} \mathrm{O}_{4}\right)$ and insulating $\left(\mathrm{Al}_{2} \mathrm{O}_{3}\right)$ nanoparticles at various concentrations on the dielectric strength of transformer mineral oil. The method of preparation and characterization of these nanofluids (NFs) through the measurements of zeta potential, the real and imaginary parts of dielectric permittivity as well as the concentration and size of nanoparticles using scanning electron microscope images of nanoparticles powders and energy dispersive $\mathrm{x}$-ray spectroscopy analysis are presented. Experimental findings reveal that these two types of nanoparticles materials significantly improve AC breakdown voltage and the magnitude of this enhancement depends on the nanoparticle concentration, and the size and nature (material) of nanoparticles. For a given type of nanoparticle, the effect is more marked with the smallest nanoparticles. The conductive nanoparticles offer higher enhancement of dielectric strength compared with insulating nanoparticle based nanofluids. With $\mathrm{Fe}_{3} \mathrm{O}_{4}$, the breakdown voltage (BDV) can exceed twice that of mineral oil and it increases by more than $76 \%$ with $\mathrm{Al}_{2} \mathrm{O}_{3}$. The physicochemical mechanisms implicated in this improvement are discussed.
\end{abstract}

Keywords: AC dielectric strength; insulating liquids; mineral oil-based nanofluids; statistical analysis; Weibull distribution; normal distribution

\section{Introduction}

The search for increasingly efficient materials of integrated components in electric power transmission and distribution systems to improve the dielectric strength, and reduce their size, weight, and cost is a permanent task. Also, nanotechnologies and, more particularly, dielectric nanofluids (NFs) constitute an innovative line of research with a promising potential and future.

The effect of nanoparticles on the electrical properties of dielectric materials, in particular, on their ability to record the initiation voltage of partial discharges and to slow the propagation of electrical discharges, trees in polymers and streamers in liquids, leading to breakdown is the subject of many studies around the world for the past 20 years. It appears from the results reported in the literature that some polymers' nano-composites are promising materials for high voltage applications [1-6]. The fact that nano-materials present interesting dielectric characteristics results from the large volume fraction of interfaces in the bulk of the material and the ensuing interactions between the surface of the charged nanomaterial and the molecular structure of the hosting material. However, if the solid dielectrics provide a function mainly of insulation and mechanical support (equipment envelope, support isolators, bushing, etc.), the liquid dielectrics must ensure the thermal transfer for a better cooling of high voltage components and power transformers especially, in addition to their insulating role. 
This cooling property (heat transfer) was at the origin of NFs' development. Nowadays, NFs are used in several fields, like electronics (chips, electronic circuitry components); transportation (the cooling systems of heavy power machines and heat generation parts of vehicles); heating buildings and reducing pollution; nuclear cooling systems; space and defense (space stations and aircrafts); and solar absorption for heat-transfer performance. Indeed, they have preferable better thermal characteristics (thermal diffusivity, thermal conductivity, convective coefficient of heat transfer) than the base fluids. These strongly depend on properties and the volume fraction of the added nanomaterial $[7,8]$. Furthermore, for a given particles volume, the contact area of the solid-liquid surface between nano-size particles and the suspension fluid is greater than that for micro-size particles. Therefore, the shape and size of particles has a clear impact on heat transfer and thermal conductivity characteristics [9-11].

The volume fraction of particles (concentration), their shape and size, and the surface contact area between particles and liquid are major parameters that influence not only the thermal properties as indicated above, but also have a very great influence on the dielectric properties of composite materials. It is in search of new liquid dielectrics ensuring these functions that the present study fits.

In recent years, research on transformer oil-based NFs have been the subject of particular attention. Much effort has been focused on the dielectric and thermal properties of some NFs for use in power transformers [12-18]. It has been reported that NFs, especially magnetic NFs, present better AC and DC breakdown voltages and thermal conductivity than base oils [19-21]. Segal et al. [13] observed that the positive impulse breakdown voltage of these types of NFs is almost twice of the base transformer oil. Qi Wang et al. [22] observed that the positive lightning impulse breakdown voltage of three types of transformer oil-based $\mathrm{Al}_{2} \mathrm{O}_{3}, \mathrm{TiO}_{2}$, and $\mathrm{Fe}_{3} \mathrm{O}_{4}$ nanofluids increases with the concentration of nanoparticles up to a critical value of concentration; beyond this concentration, it starts decreasing. The improvement of negative impulse breakdown voltages was less than that of pure transformer oil. An enhancement of $33 \%$ to $36.1 \%$ with $\mathrm{Al}_{2} \mathrm{O}_{3}$ and $38.8 \%$ to $50 \%$ of $\mathrm{Fe}_{3} \mathrm{O}_{4}$ of pure mineral oil has been reported by Madavan et al. [23]. Dhar et al. [24] reported that the addition of traces of graphene or carbon nanotubes (CNT) improves the AC dielectric breakdown strength of insulating mineral oils by about $70 \%$ to $80 \%$. Peppas et al. [25] observed that an NF of surface coated in $\mathrm{Fe}_{3} \mathrm{O}_{4}$ nanoparticles improves the AC BDV of natural ester (FR3) and mineral (Shell Diala) oils. However, some authors have reported contradictory results [26]. They observed that the AC breakdown voltage, with the conducting particles as $\mathrm{Fe}_{2} \mathrm{NiO}_{4}$, decreases when the concentration of nanoparticles increases.

This work is aimed at investigating the effect of two kinds of nanoparticles (insulating and conductive), namely $\mathrm{Fe}_{3} \mathrm{O}_{4}$ and $\mathrm{Al}_{2} \mathrm{O}_{3}$, on the $\mathrm{AC}$ dielectric strength of transformer mineral oil. We first present the preparation of nanofluids and then some characteristics, such as the zeta potential, to check the stability of NFs, and the real and imaginary parts of dielectric permittivity. The concentration and size of nanoparticles using scanning electron microscope images of nanoparticles powders and energy dispersive x-ray spectroscopy analysis are also conducted. Then, the results of $\mathrm{AC}$ breakdown voltage measurements of mineral oil-based $\mathrm{Fe}_{3} \mathrm{O}_{4}$ and $\mathrm{Al}_{2} \mathrm{O}_{3}$ nanofluids are presented and the physicochemical processes implicated in the breakdown phenomena of nanofluids are discussed.

\section{Experiment}

\subsection{Preparation and Characterization of Nanofluid Samples}

The nanoparticles used in this study were supplied from Sigma-Aldrich and have a purity of 99.9\%. These were conductive $\left(\mathrm{Fe}_{3} \mathrm{O}_{4}\right)$ and insulating $\left(\mathrm{Al}_{2} \mathrm{O}_{3}\right)$. Their mean sizes were $50 \mathrm{~nm}$ for $\mathrm{Fe}_{3} \mathrm{O}_{4}$, and $13 \mathrm{~nm}$ and $50 \mathrm{~nm}$ for $\mathrm{Al}_{2} \mathrm{O}_{3}$. Figure 1 gives the distribution of the various nanoparticles we used in mineral oil. It was measured by using a particle size analyzer (NanoPlus, Particulate Systems, USA). Scanning electron microscope (SEM) images show that these nanoparticles were near spherical in shape even if some aggregates can be observed as shown in Figure 2a. Figure $2 b$ shows the peaks corresponding to the species present in the nanoparticles as evidenced by energy dispersive $\mathrm{X}$-ray spectroscopy (EDS) analysis. 
The EDS analysis confirms the presence of each sample composition at the atomic percentage. The characteristic parameters of the basic mineral oil we used are shown in Table 1.

Note that because of the aged mineral oil we used, its water content is higher than that of the fresh oil, which generally does not exceed $8 \mathrm{ppm}$. This fact would affect the experimental results. However, as all nanofluid samples were prepared with the same base oil, the comparison of our results/comparison will be done on the same basis.

Mineral-oil nanofluids were prepared by dispersion of nanoparticles in a concentration ranging from $0.05 \mathrm{~g} / \mathrm{L}$ to $0.4 \mathrm{~g} / \mathrm{L}$. After the magnetic stirring process for $30 \mathrm{~min}$, the NFs samples were submitted to an ultra-sonication process (i.e., NFs were placed in the ultrasonic homogenizer) for $2 \mathrm{~h}$ to avoid agglomeration and clusters due to attractive and repulsive forces.

In order to reach a stable suspension of nanoparticles in oil, further ultrasonification was applied for only a 2 min duration using a Sonics Vibra-cell sonicator $(750 \mathrm{~W}$ power rating, $20 \mathrm{kHz}$ capability, and 0.5 inch probe) to avoid reunion of nanoparticles without the need of adding any surfactant. Then, all samples were moved into a vacuum chamber of $0.16 \mathrm{MPa}$ for $24 \mathrm{~h}$ for drying and removal of internal micro bubbles formed during the ultrasonication process.

The stability of NFs we prepared was checked through the measurements of the zeta potential ( $\zeta$-potential), by using Malvern Zeta sizer nano ZS 90-UK, which is a key indicator of the stability of suspensions. The magnitude of the $\zeta$-potential indicates the degree of electrostatic repulsion between adjacent, similarly charged particles in a dispersion. For particles that are small enough, a high zeta potential refers to higher stability and, consequently, the dispersion becomes more stable without agglomerations. Table 2 gives the zeta potential for four NFs and mineral oil for comparison. It was observed that the absolute value of the $\zeta$-potential increases with the concentration of nanoparticles. Additionally, for a given concentration $(0.3 \mathrm{~g} / \mathrm{L}$ for instance), this value was higher for $\mathrm{Al}_{2} \mathrm{O}_{3}$ nanoparticles than that for $\mathrm{Fe}_{3} \mathrm{O}_{4}$.

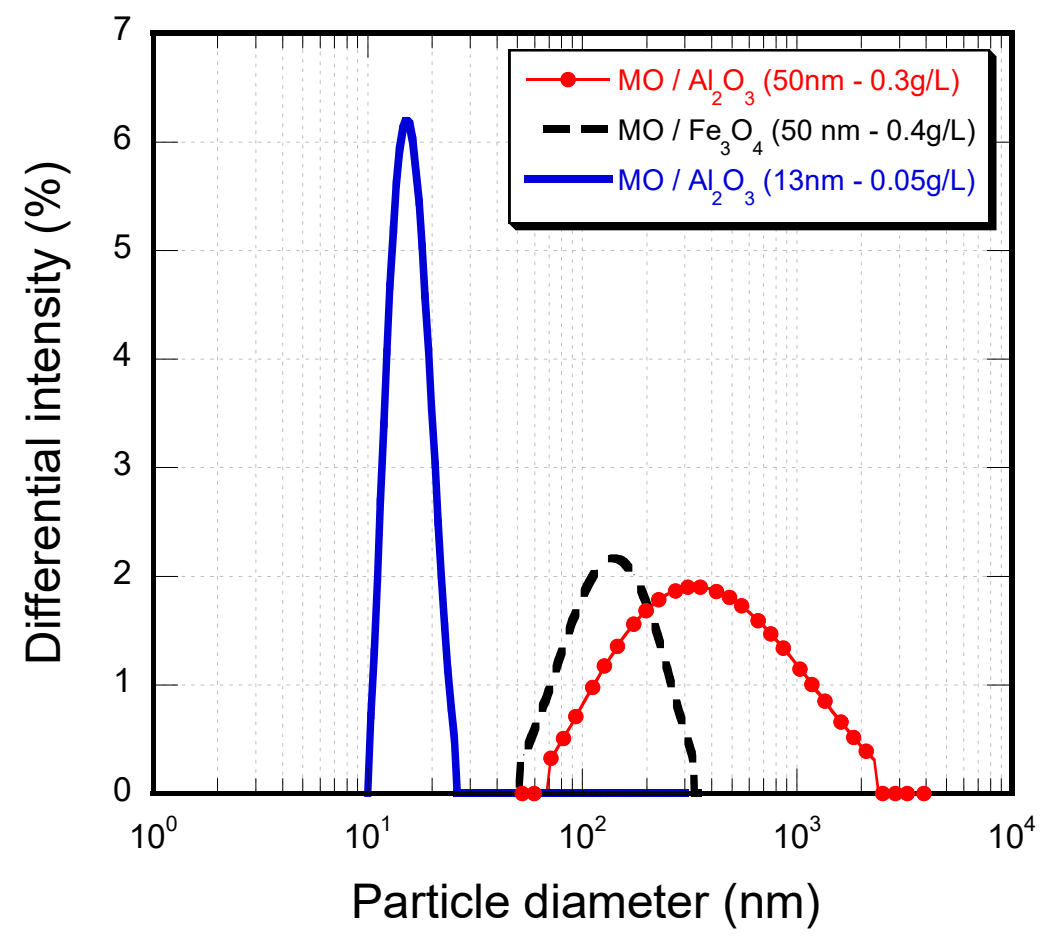

Figure 1. Particles size analysis of nanofluid samples. 

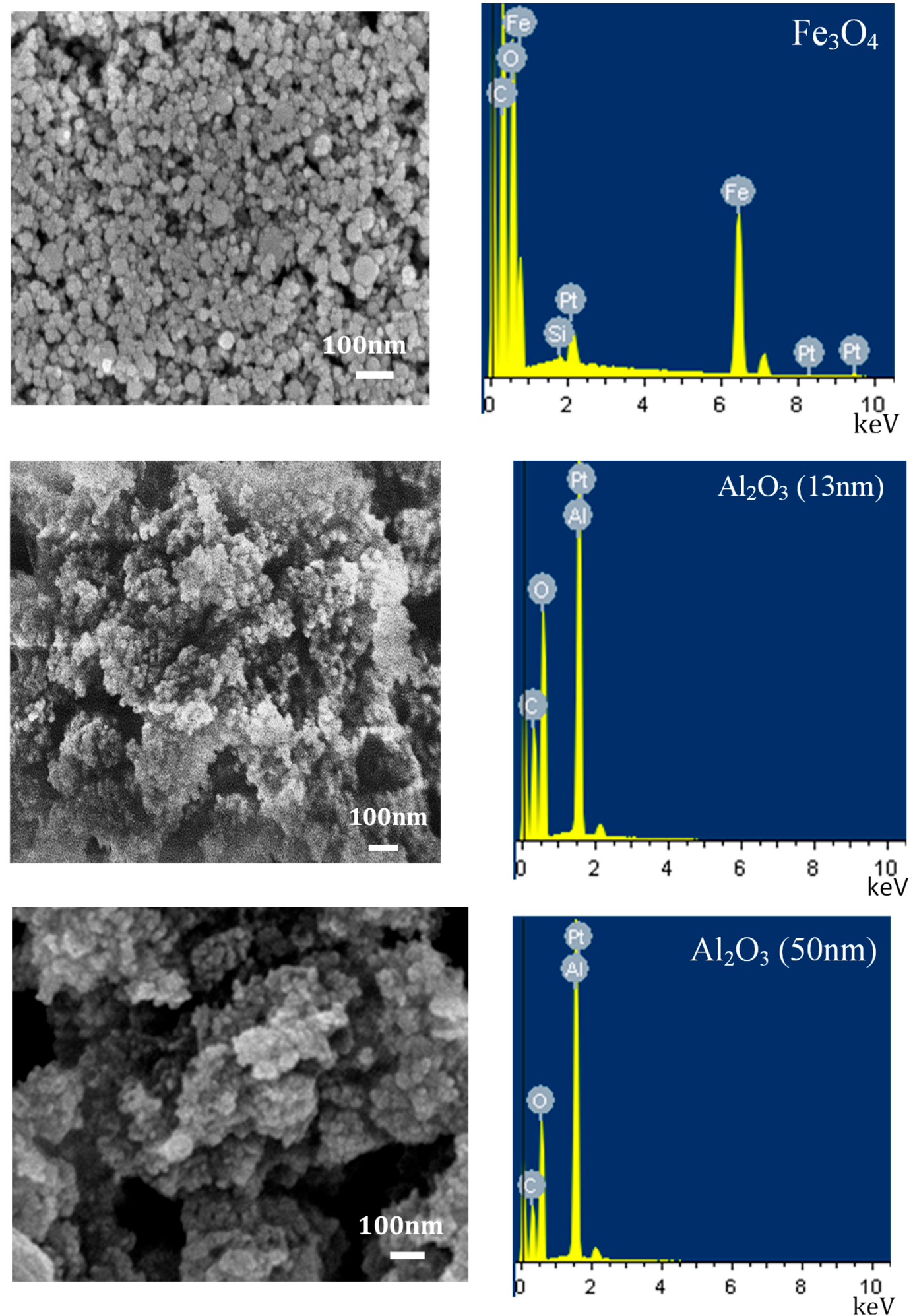

(a)

(b)

Figure 2. (a) Scanning electron microscope (SEM) and (b) EDS images of nanoparticles. 
Table 1. Physicochemical properties of mineral oil.

\begin{tabular}{lc}
\hline \multicolumn{1}{c}{ Property } & Mineral Oil \\
\hline Density at $25^{\circ} \mathrm{C}(\mathrm{g} / \mathrm{mL})$ & 0.85 \\
Kinematic viscosity at $40{ }^{\circ} \mathrm{C}(\mathrm{cSt})$ & 9 \\
Pour point $\left({ }^{\circ} \mathrm{C}\right)$ & -40 \\
Flash point $\left({ }^{\circ} \mathrm{C}\right)$ & 150 \\
Fire point $\left({ }^{\circ} \mathrm{C}\right)$ & 160 \\
Total acid number $(\mathrm{mg} \mathrm{KOH} / \mathrm{g})$ & $<0.5$ \\
Antioxidant content & $<0.3 \%$ \\
Water content $(\mathrm{ppm})$ & 39 \\
Gassing characteristics $\left(\mathrm{mm}^{3} / \mathrm{min}\right)$ & $-35-30$ \\
Interfacial tension $(\mathrm{mN} / \mathrm{m})$ & $40 \sim 60$ \\
Resistivity $(\Omega \cdot \mathrm{m})$ & $>3 \times 10^{9}$ \\
Dissipation factor at $90{ }^{\circ} \mathrm{C}$ & $0.1-0.5 \%$ \\
\hline
\end{tabular}

Table 2. Zeta potential and electrical conductivity of the tested nanofluids.

\begin{tabular}{ccc}
\hline Tested Nanofluids & Zeta Potential $(\mathbf{m V})$ & Electrical Conductivity $(\mathbf{m S} / \mathbf{c m}) \times \mathbf{1 0}^{\mathbf{3}}$ \\
\hline $\mathrm{MO}$ & +15.1 & 0.212 \\
$\mathrm{MO} / \mathrm{Al}_{2} \mathrm{O}_{3}(0.05 \mathrm{~g} / \mathrm{L})$ & -3.44 & 1.02 \\
$\mathrm{MO} / \mathrm{Al}_{2} \mathrm{O}_{3}(0.3 \mathrm{~g} / \mathrm{L})$ & +16.5 & 0.58 \\
$\mathrm{MO} / \mathrm{Fe}_{3} \mathrm{O}_{4}(0.3 \mathrm{~g} / \mathrm{L})$ & -10.3 & 1.21 \\
$\mathrm{MO} / \mathrm{Fe}_{3} \mathrm{O}_{4}(0.4 \mathrm{~g} / \mathrm{L})$ & -26.9 & 1.43 \\
\hline
\end{tabular}

The measurements of electrical conductivity show that the $\mathrm{Fe}_{3} \mathrm{O}_{4}$ based NF were higher than that of $\mathrm{Al}_{2} \mathrm{O}_{3}$ for the same concentration of nanoparticles, as shown in Table 2. This was due to the fact that $\mathrm{Fe}_{3} \mathrm{O}_{4}$ conducts more than $\mathrm{Al}_{2} \mathrm{O}_{3}$, which is known as a good insulating material.

Figure 3 depicts the real and imaginary parts of the dielectric permittivity of the investigated NF versus the frequency up to $100 \mathrm{~Hz}$. These measurements were performed by a HIOKI-LCR meter IM3536, Japan. We observed that the real part of the dielectric permittivity decreases abruptly in the range of $0 \mathrm{~Hz}-40 \mathrm{~Hz}$ and then tends to be constant.

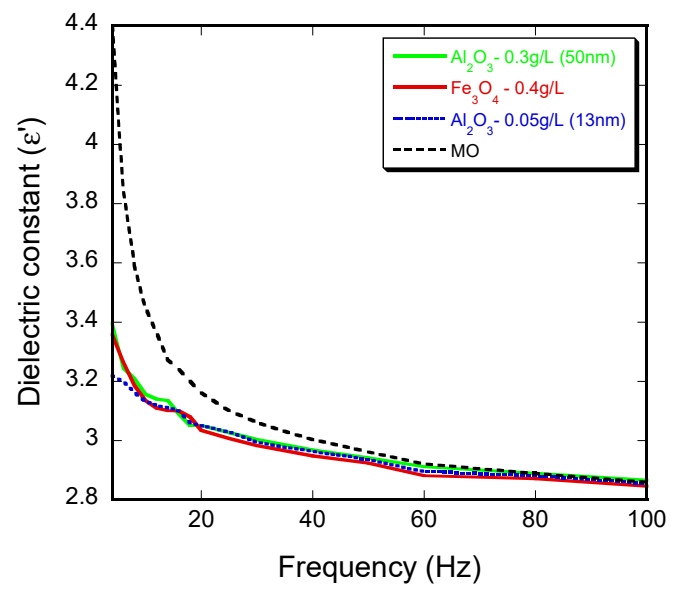

(a)

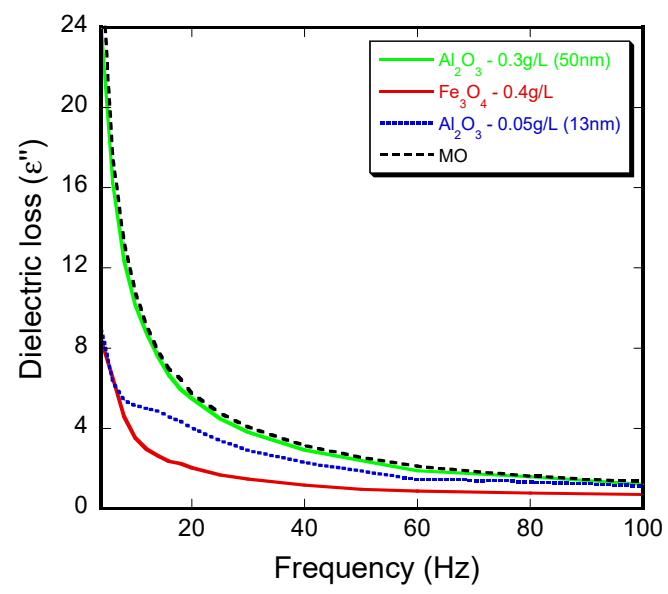

(b)

Figure 3. (a) Real and (b) imaginary parts of the relative dielectric permittivity vs. the frequency of the investigated nanofluids.

At $50 \mathrm{~Hz}-60 \mathrm{~Hz}$, which corresponds to industrial frequencies, the real part of the dielectric permittivity of nanofluid samples was practically the same as that of the base oil (mineral oil). Similarly, this was also observed with the imaginary part of the dielectric permittivity. 


\subsection{Breakdown Voltage Measurement}

The breakdown voltage (BDV) measurements were achieved according to the IEC 60156 standard [27] and using a test cell of a $500 \mathrm{~mL}$ volume and an oil tester (Foster Oil Test 90 type). The electrode arrangement consisted of two copper hemispheres of a $12.5 \mathrm{~mm}$ diameter; the gap distance between the electrodes was kept at $2.50 \pm 0.05 \mathrm{~mm}$. Both electrodes and the test cell were also prepared according to the IEC 60156 specifications. The voltage was continuously applied at the electrodes at a uniform rise rate of $2 \pm 0.2 \mathrm{kV} / \mathrm{s}$ until the breakdown occurred. The breakdown voltage was the average of 16 successive measurements and the time delay between successive measurements was $2 \mathrm{~min}$. Sixteen (16) is a proper number for a Weibull statistical analysis. This enables us to have a power of two $\left(2^{4}=16\right)$ and to deduce the slope of the Weibull graphs [28].

\section{Experimental Results}

Figures 4-6 show the Weibull probabilities of the AC breakdown voltage of mineral oil-based $\mathrm{Fe}_{3} \mathrm{O}_{4}$ and $\mathrm{Al}_{2} \mathrm{O}_{3}$ nanofluids for different concentrations of particles and size. In addition, Table 3 gives the AC breakdown voltage at breakdown probabilities of $1 \%, 10 \%$, and $50 \%$ for the three investigated NFs, which were read from the distinctive Weibull plots. Further, these tables show the incremental percentage of the mineral oil with different concentrations of nanofluids. The breakdown voltage at the $1 \%$ cumulative probability is estimated to be the minimum possible breakdown voltage, and so, refers to the reliability of oil. Generally, the BDV of nanofluids were higher than that of the pure mineral oil whatever the type and size of nanoparticles.

The indications within the inserts are: (1) The shape parameter that is equal to the slope of the line in a probability plot, which affects the shape of the curve; (2) the scale parameter, which is related to the scattering of the data, and indicates the degree of failure; (3) the Anderson-Darling (AD) value that is the Anderson-Darling measure of the area between the fitted line and the empirical distribution function, which is based on the data points; (4) $\mathrm{N}$ is the number of breakdown voltage data points; and (5) the $p$-value is a probability that measures the evidence against the null hypothesis.

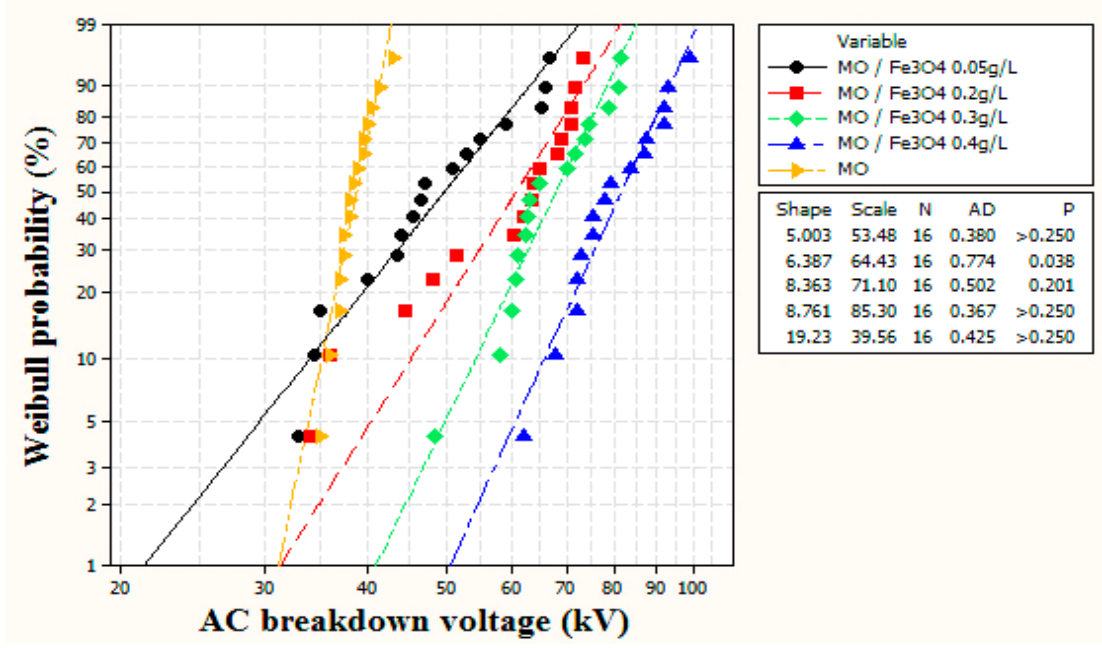

Figure 4. Weibull probability of the average reading of the breakdown voltage of $\mathrm{MO} / \mathrm{Fe}_{3} \mathrm{O}_{4} \mathrm{NFs}$. 


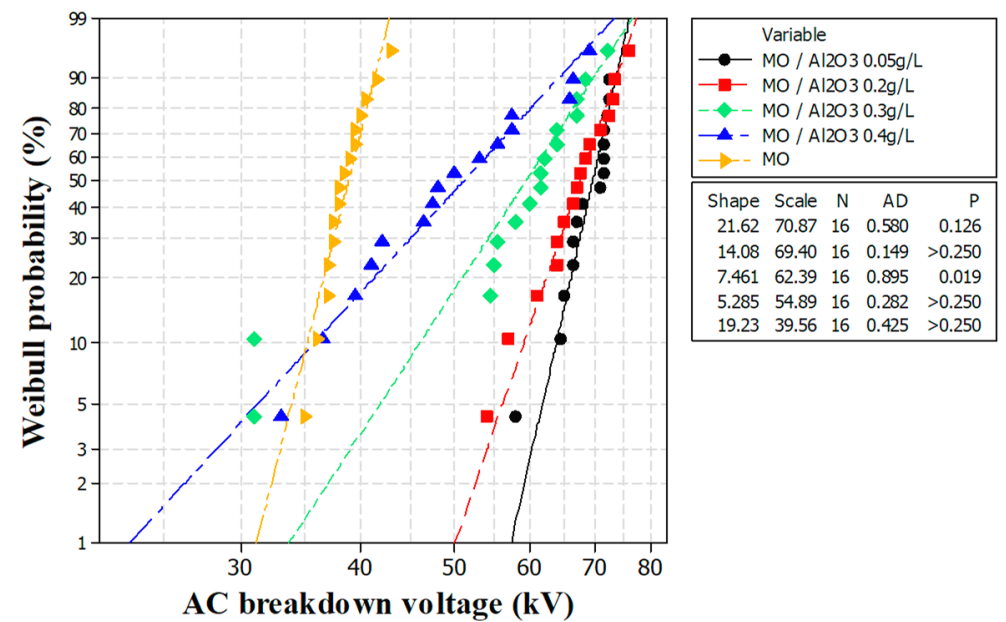

Figure 5. Weibull probability of the average reading of the breakdown voltage of $\mathrm{MO} / \mathrm{Al}_{2} \mathrm{O}_{3}$ $(13 \mathrm{~nm}) \mathrm{NFs}$.
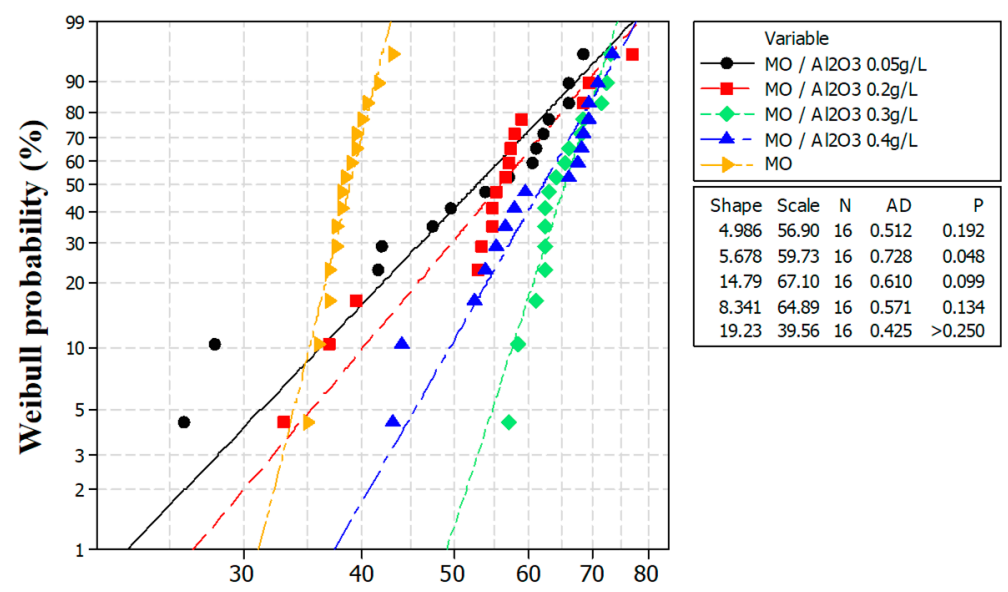

AC breakdown voltage $(\mathrm{kV})$

Figure 6. Weibull probability of the average reading of the breakdown voltage of $\mathrm{MO} / \mathrm{Al}_{2} \mathrm{O}_{3}$ $(50 \mathrm{~nm}) \mathrm{NFs}$.

Table 3. AC breakdown voltage at different breakdown probabilities of various nanofluids.

\begin{tabular}{|c|c|c|c|c|c|c|c|c|c|}
\hline \multirow{2}{*}{$\begin{array}{c}\text { BDV } \\
\text { Probability } \\
(\%)\end{array}$} & \multirow{2}{*}{$\begin{array}{l}\text { MO } \\
\text { BDV } \\
(\mathrm{kV})\end{array}$} & \multicolumn{2}{|c|}{$0.05 \mathrm{~g} / \mathrm{L}$} & \multicolumn{2}{|c|}{$0.2 \mathrm{~g} / \mathrm{L}$} & \multicolumn{2}{|c|}{$0.3 \mathrm{~g} / \mathrm{L}$} & \multicolumn{2}{|c|}{$0.4 \mathrm{~g} / \mathrm{L}$} \\
\hline & & $\begin{array}{l}\text { BDV } \\
(\mathrm{kV})\end{array}$ & $\begin{array}{c}\text { Increment } \\
(\%)\end{array}$ & $\begin{array}{l}\text { BDV } \\
(\mathbf{k V})\end{array}$ & $\begin{array}{c}\text { Increment } \\
(\%)\end{array}$ & $\begin{array}{l}\text { BDV } \\
(\mathrm{kV})\end{array}$ & $\begin{array}{c}\text { Increment } \\
(\%)\end{array}$ & $\begin{array}{l}\text { BDV } \\
(\mathrm{kV})\end{array}$ & $\begin{array}{c}\text { Increment } \\
(\%)\end{array}$ \\
\hline \multicolumn{10}{|c|}{$\mathrm{MO} / \mathrm{Fe}_{3} \mathrm{O}_{4}$} \\
\hline 1.0 & 31.1 & 21.3 & -31.6 & 31.3 & 0.5 & 41.0 & 31.7 & 50.5 & 62.2 \\
\hline 10.0 & 35.2 & 34.1 & -3.1 & 45.3 & 28.7 & 54.3 & 54.3 & 66.0 & 87.5 \\
\hline 50.0 & 38.8 & 50.0 & 28.8 & 60.8 & 56.7 & 68.0 & 75.2 & 81.0 & 108.7 \\
\hline \multicolumn{10}{|c|}{$\mathrm{MO} / \mathrm{Al}_{2} \mathrm{O}_{3}(13 \mathrm{~nm})$} \\
\hline 1.0 & 31.1 & 57.3 & 84.0 & 50.0 & 60.6 & 33.6 & 7.9 & 23.0 & -26.2 \\
\hline 10.0 & 35.2 & 63.9 & 81.4 & 59.1 & 67.9 & 46.1 & 31.1 & 35.9 & 1.8 \\
\hline 50.0 & 38.8 & 69.7 & 79.6 & 67.6 & 74.2 & 59.4 & 53.1 & 51.2 & 31.9 \\
\hline \multicolumn{10}{|c|}{$\mathrm{MO} / \mathrm{Al}_{2} \mathrm{O}_{3}(50 \mathrm{~nm})$} \\
\hline 1.0 & 31.1 & 22.7 & -27.1 & 26.5 & -14.9 & 49.1 & 57.7 & 37.4 & 20.1 \\
\hline 10.0 & 35.2 & 36.2 & 2.8 & 40.2 & 14.2 & 57.6 & 63.6 & 49.5 & 40.6 \\
\hline 50.0 & 38.8 & 52.9 & 36.3 & 56.0 & 44.3 & 65.5 & 68.8 & 62.1 & 60.0 \\
\hline
\end{tabular}


It was observed that the BDV of mineral oil-based $\mathrm{Fe}_{3} \mathrm{O}_{4}$ increased with the concentration of nanoparticles as shown in Figure 4. With a concentration of $0.4 \mathrm{~g} / \mathrm{L}$, the average BDV of NF exceeds twice that of mineral oil alone (Figure 7). This is of a great interest for the oil-filled apparatus, especially for the power transformer. While for mineral oil-based $\mathrm{Al}_{2} \mathrm{O}_{3}$ with nanoparticles of $13 \mathrm{~nm}$, the average BDV increased up to a maximum value (optimal), which was reached at a small concentration of $0.05 \mathrm{~g} / \mathrm{L}$; this increase is of $72 \%$ with respect to that of mineral oil and then decreased, but remained higher than that of mineral oil (Figure 8). While with nanoparticles of $50 \mathrm{~nm}$, the optimal average $\mathrm{BDV}$ was reached at a higher concentration of $0.3 \mathrm{~g} / \mathrm{L}$ and the increase was of $69 \%$ (Figure 9). Table 4 summarizes the median and average breakdown voltages of the tested $\mathrm{MO} / \mathrm{NFs}$ samples.

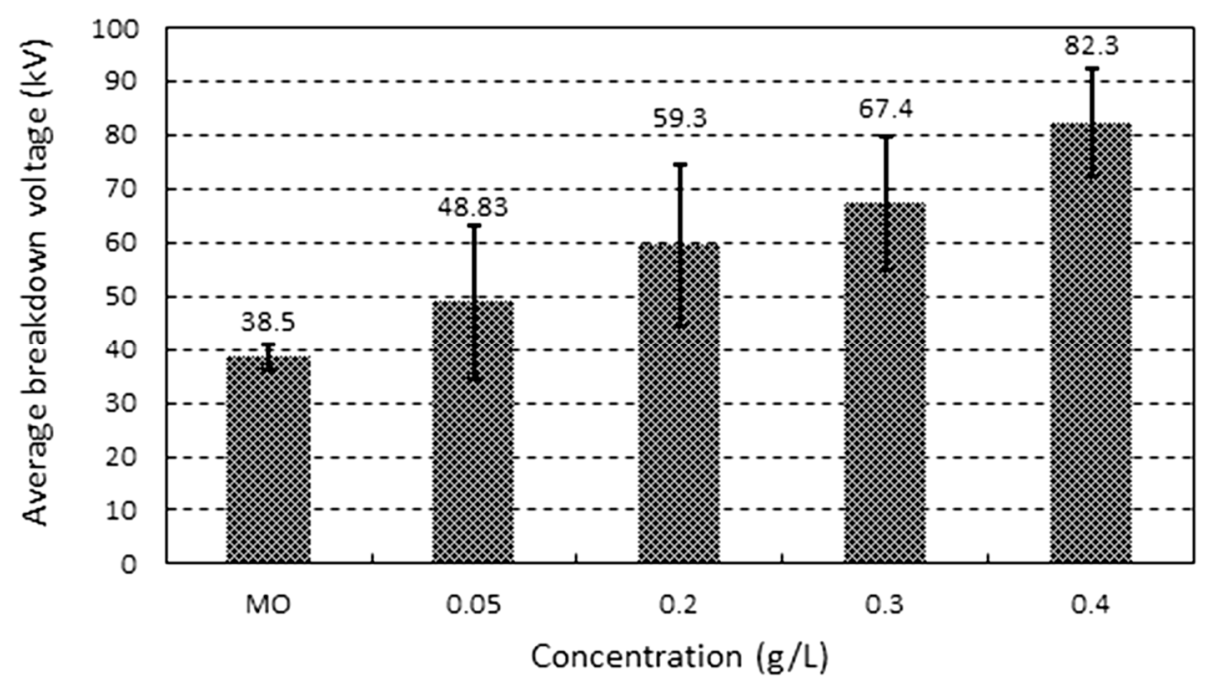

Figure 7. The breakdown voltages of $\mathrm{MO} / \mathrm{Fe}_{3} \mathrm{O}_{4} \mathrm{NFs}$.

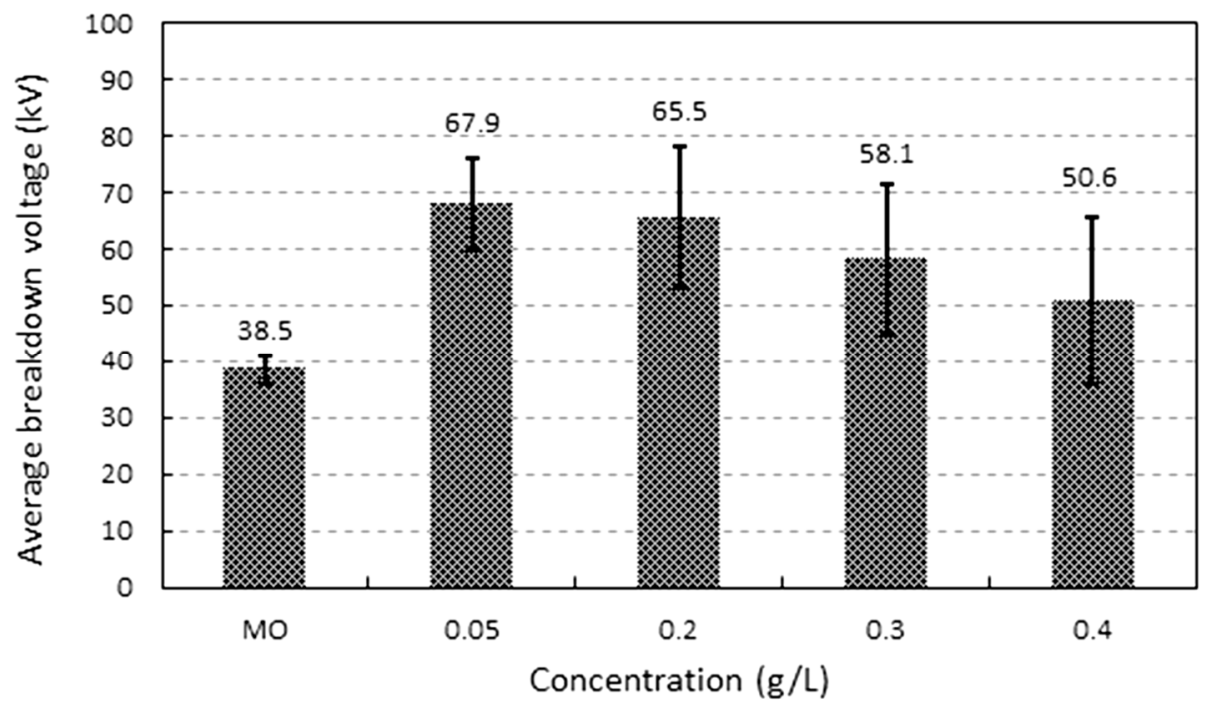

Figure 8. The breakdown voltages of $\mathrm{MO} / \mathrm{Al}_{2} \mathrm{O}_{3}(13 \mathrm{~nm}) \mathrm{NFs}$. 


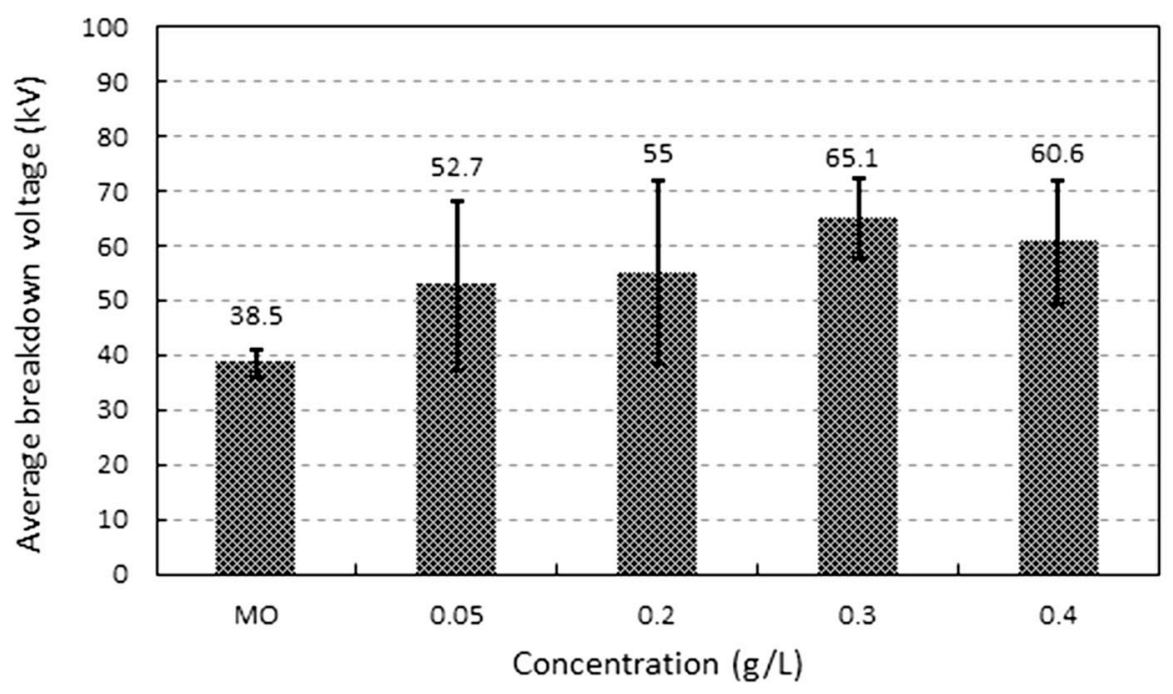

Figure 9. The breakdown voltages of $\mathrm{MO} / \mathrm{Al}_{2} \mathrm{O}_{3}(50 \mathrm{~nm}) \mathrm{NFs}$.

Table 4. The median and average breakdown voltages of tested MO/NFs samples.

\begin{tabular}{|c|c|c|c|c|c|}
\hline $\begin{array}{l}\text { NF Samples and } \\
\text { Concentrations }\end{array}$ & MO & $0.05 \mathrm{~g} / \mathrm{L}$ & $0.2 \mathrm{~g} / \mathrm{L}$ & $0.3 \mathrm{~g} / \mathrm{L}$ & $0.4 \mathrm{~g} / \mathrm{L}$ \\
\hline \multicolumn{6}{|c|}{ Median BDV (50\% probability), kV } \\
\hline $\mathrm{MO} / \mathrm{Fe}_{3} \mathrm{O}_{4}$ & \multirow{3}{*}{38.80} & 50.00 & 60.80 & 68.00 & 81.00 \\
\hline $\mathrm{MO} / \mathrm{Al}_{2} \mathrm{O}_{3}(13 \mathrm{~nm})$ & & 69.70 & 67.60 & 59.40 & 51.20 \\
\hline $\mathrm{MO} / \mathrm{Al}_{2} \mathrm{O}_{3}(50 \mathrm{~nm})$ & & 52.90 & 56.00 & 65.50 & 62.10 \\
\hline \multicolumn{6}{|c|}{ Average BDV, kV } \\
\hline $\mathrm{MO} / \mathrm{Fe}_{3} \mathrm{O}_{4}$ & \multirow{3}{*}{38.50} & 48.83 & 59.30 & 67.40 & 82.30 \\
\hline $\mathrm{MO} / \mathrm{Al}_{2} \mathrm{O}_{3}(13 \mathrm{~nm})$ & & 67.90 & 65.50 & 58.10 & 50.60 \\
\hline $\mathrm{MO} / \mathrm{Al}_{2} \mathrm{O}_{3}(50 \mathrm{~nm})$ & & 52.70 & 55.00 & 65.10 & 60.60 \\
\hline
\end{tabular}

\section{Discussion}

It appears from Table 4 that at concentrations of $0.05 \mathrm{~g} / \mathrm{L}$ and $0.20 \mathrm{~g} / \mathrm{L}$, the highest average breakdown voltage was obtained with $\mathrm{Al}_{2} \mathrm{O}_{3}$ nanoparticles of $13 \mathrm{~nm}$; the average $\mathrm{BDV}$ was increased by $76.6 \%$ with respect to mineral oil. While with $\mathrm{Al}_{2} \mathrm{O}_{3}$ nanoparticles of $50 \mathrm{~nm}$, the increase was $36.3 \%$ for the same concentration. This increase was only $28.9 \%$ with $\mathrm{Fe}_{3} \mathrm{O}_{4}$.

With concentrations of $0.3 \mathrm{~g} / \mathrm{L}$ and $0.4 \mathrm{~g} / \mathrm{L}$, the maximum average BDV was obtained with $\mathrm{Fe}_{3} \mathrm{O}_{4}$ nanoparticles. The improvement was $75.3 \%$ and $108.8 \%$ with respect to mineral oil, respectively. Table 3 presents a comparison of different NFs of different volume concentrations with mineral oil. The fact that with the same kind of nanoparticles and concentration, the average BDV was higher with smaller nanoparticles is due to the large volume fraction of interfaces in the bulk of the material and the ensuing interactions between the charged nanomaterial surface and the liquid molecule.

It was observed that improvements with the same nanoparticles, such as Madawan et al. [23], are two times higher than the ones reported by these authors. Also, our findings confirm those reported by a number of authors [13,19-23] and contradict others [26] regarding concerns of the influence of $\mathrm{Al}_{2} \mathrm{O}_{3}$ and $\mathrm{Fe}_{3} \mathrm{O}_{4}$ nanoparticles on the breakdown voltage of mineral oil.

The increase of the breakdown voltage of liquid (MO) when adding some amounts of nanoparticles results from their influence on the physicochemical processes evolving during the pre-breakdown phase that are mainly the conduction, the initiation, and/or propagation of streamers. The question is: How and which mechanism(s)? In the following, we analyze the possible implication of each one of these mechanisms. If the nanoparticles (NPs) act on the conduction, they likely act as 
charge carriers' scavengers. Thus, by reducing the number of charges by trapping and, consequently, the total space charge, the liquid becomes less conductive and its breakdown voltage increases.

Table 2 seems to contradict that hypothesis since the conductivity of liquid increases when increasing the amount of nanoparticles. Therefore, the nanoparticles would act on the streamers' phenomena. The influence of electronic scavenger additives (especially halogenated molecules) has been investigated by many researchers and it was established unanimously that such additives accelerate the streamer propagation velocity [29-32]. However, the interpretations concerning the effect of this streamer acceleration on the breakdown voltage were contradictory. Most authors deduced that the fact that the streamers are more rapid leads to the decrease of the breakdown voltage [29]. Beroual [31,33], and Beroual and Aka [34] showed that the electronic scavengers' additives increase the initiation threshold voltage of streamers, thus increasing the voltage and therefore its energy: The streamer, being more energetic, results in its velocity also being higher [31].

In our case, the nanoparticles acted at two levels: (1) At the electrodes interfaces by constituting a barrier, which reduces the injected charges into the liquid and their mobility. Therefore, the initiation threshold voltage of streamers increased and the breakdown voltage was higher; and (2) at the nanoparticles/hosting liquid interfaces by constituting double layers. The charge carriers were trapped up to saturation. The fact that there was an optimum concentration of NPs is likely due do to some saturation of NPs/hosting oil interfaces. On the other hand, the dielectric permittivity (real part) of $\mathrm{Fe}_{3} \mathrm{O}_{4}$ being significantly higher than that of $\mathrm{Al}_{2} \mathrm{O}_{3}$ results in a higher surface charge with the $\mathrm{Fe}_{3} \mathrm{O}_{4} \mathrm{NPs} /$ base oil. $\mathrm{Fe}_{3} \mathrm{O}_{4}$, being more conductive, could easily be charged and polarized than $\mathrm{Al}_{2} \mathrm{O}_{3}$. These phenomena (polarization, double layer, and trapping) explain the greater improvement with conductive nanoparticles.

According to Hwang et al. [35], nanoparticles with different conductivity or permittivity than those of the matrix oil enhance the breakdown voltage strength while the insertion of nanoparticles with a conductivity and permittivity comparable to those of the matrix oil results in the decrease of the breakdown voltage. It is difficult to accept such an interpretation because in some cases, beyond a certain concentration (optimal concentration) of nanoparticles, the breakdown voltage decreases.

The role of nanoparticles as electronic scavengers has been also advanced by Peppas et al. [36] and Makmud et al. [37] to explain the improvement of the breakdown voltage. They attributed this improvement to the effective electron scavenging by the nanostructures, which results in delaying the development of streamers and reducing their propagation velocity.

The mechanism of trapping electrons has also been proposed by some researchers $[26,38,39]$ to explain the higher breakdown strength of conducting nanofluids compared to base oils. The conductive nanoparticles capture very rapidly fast moving electrons and convert into slow negatively charged nanoparticles, resulting in the slowing of the streamer propagation (i.e., reduction of streamer velocity) and therefore increasing the breakdown voltage.

As indicated above, such an interpretation through the slowing propagation of streamers remains a subject of discussion; the electronic scavenger additives accelerate the propagation of streamers [29-32]. Another possibility, which would explain the improvement of the breakdown voltage, is the result of electron trapping by nanoparticles: Conductive nanoparticles trap electrons by charge induction, such is the case of $\mathrm{Fe}_{3} \mathrm{O}_{4}$, while nonconductive nanoparticles, which are $\mathrm{Al}_{2} \mathrm{O}_{3}$, trap electrons due to polarization [39].

On the other hand, the fact that for the same concentration of nanoparticles, the dielectric strength is higher for smaller nanoparticles is due to the large volume fraction of interfaces (more surfaces for charges accumulation) in the bulk of the liquid and the ensuing interactions between the charge nanoparticles' surface and the molecular structure of the liquid. There are few displacements toward the opposite electrode, thus slowing the propagation of streamers. 


\section{Conclusions}

In this work, the $\mathrm{AC}$ breakdown voltages of mineral oil-based $\mathrm{Fe}_{3} \mathrm{O}_{4}$ and $\mathrm{Al}_{2} \mathrm{O}_{3}$ nanofluids (NFs) were investigated. The preparation and physicochemical characterization of these nanofluids were presented.

It has been highlighted that the AC breakdown voltage of these NFs are higher than that of mineral oil. The magnitude of this improvement depends on the concentration, and the size and type of nanoparticles. For a given type of nanoparticles, the effect is more marked with the smallest nanoparticles. The conductive nanoparticles $\left(\mathrm{Fe}_{3} \mathrm{O}_{4}\right)$ offer a higher enhancement of the dielectric strength compared to insulating nanoparticles based nanofluids. With $\mathrm{Fe}_{3} \mathrm{O}_{4}$, the breakdown voltage (BDV) can exceed twice that of mineral oil and it increases by more than $76 \%$ with $\mathrm{Al}_{2} \mathrm{O}_{3}$. The possible mechanisms implicated in the improvement of BDV were discussed.

Therefore, these nanofluids not only have very good cooling performances, but they can also be considered for use in high voltage power transformers.

Author Contributions: Both authors contribute to conceptualization; Methodology and Software; Validation; Formal Analysis; Investigation; Writing-Review \& Editing; Project Administration and Funding Acquisition, U.K.

Funding: This research was funded by King Saud University grant number ISPP\#47.

Acknowledgments: The authors extend their appreciation to the International Scientific Partnership Program (ISPP) at King Saud University for funding this research work through ISPP\#47.

Conflicts of Interest: The authors declare no conflicts of interest.

\section{References}

1. Tanaka, T.; Montanari, G.; Mulhaupt, R. Polymer nanocomposites as dielectrics and electrical insulation-Perspectives for processing technologies, material characterization and future applications. IEEE Trans. Dielectr. Electr. Insul. 2004, 11, 763-784. [CrossRef]

2. Tanaka, T. Dielectric nanocomposites with insulating properties. IEEE Trans. Dielectr. Electr. Insul. 2005, 12, 914-928. [CrossRef]

3. Singha, S.; Thomas, M. Dielectric properties of epoxy nanocomposites. IEEE Trans. Dielectr. Electr. Insul. 2008, 15, 12-23. [CrossRef]

4. Tanaka, T. Dielectric breakdown in polymer nanocomposites. In Polymer Nanocomposites; Springer: Berlin, Germany, 2016; pp. 113-137.

5. Fréchette, M. Reflections on nanotechnology applied to dielectrics in a context of electrotechnical applications. In Proceedings of the SPE Polyolefins and Flexpack Conference, Houston, TX, USA, 27 February-2 March 2011.

6. David, E.; Fréchette, M.; Zazoum, B.; Daran-Daneau, C.; Ngô, A.D.; Couderc, H. Dielectric properties of PE/Clay nanocomposites. J. Nanomater. 2013, 2013, 703940. [CrossRef]

7. Xuan, Y.; Li, Q. Heat transfer enhancement of nanofluids. Int. J. Heat Fluid Flow 2000, 21, 58-64. [CrossRef]

8. Eastman, J.A.; Choi, S.U.; Li, S.; Yu, W.; Thompson, L.J. Anomalously increased effective thermal conductivities of ethylene glycol-based nanofluids containing copper nanoparticles. Appl. Phys. Lett. 2001, 78, 718-720. [CrossRef]

9. Choi, S. Enhancing thermal conductivity of fluids with nanoparticles, Developments and Applications of Non-Newtonian flows. ASME J. Fluids Eng. 1995, 231, 99-105.

10. Choi, S.U.; Zhang, Z.G.; Yu, W.; Lockwood, F.E.; Grulke, E.A. Anomalous thermal conductivity enhancement in nano-tube suspensions. Appl. Phys. Lett. 2001, 79, 2252-2254. [CrossRef]

11. Godson, L.; Raja, B.; Lal, D.M.; Wongwises, S. Enhancement of heat transfer using nanofluids-An overview. Renew. Sustain. Energy Rev. 2010, 14, 629-641. [CrossRef]

12. Mdavan, R.; Sujatha, B. Investigation on effects of different types of nanoparticles on critical parameters of nano-liquid insulation systems. J. Mol. Liq. 2017, 230, 437-444.

13. Segal, V.; Hjortsberg, A.; Rabinovich, A.; Nattrass, D.; Raj, K. AC (60 Hz) and impulse breakdown strength of a colloidal fluid based on transformer oil and magnetite nanoparticles. In Proceedings of the 1998 IEEE International Symposium on Electrical Insulation, Arlington, VA, USA, 7-10 June 1998; pp. 619-622. 
14. Lv, Y.; Wang, W.; Ma, K.; Zhang, S.; Zhou, Y.; Li, C.; Wang, Q. Nanoparticles effect on dielectric breakdown strength of transformer oil-based nanofluids. In Proceedings of the 2013 Annual Report Conference on Electrical Insulation and Dielectric Phenomena, Shenzhen, China, 20-23 October 2013; pp. 680-682.

15. Du, Y.; Lv, Y.; Li, C.; Chen, M.; Zhong, Y.; Zhou, J.; Li, X.; Zhou, Y. Effect of semiconductive nanoparticles on insulating performances of transformer oil. IEEE Trans. Dielectr. Electr. Insul. 2012, 19, 770-776.

16. Du, Y.; Lv, Y.; Li, C.; Chen, M.; Zhou, J.; Li, X.; Zhou, Y.; Tu, Y. Effect of electron shallow trap on breakdown performance of transformer oil-based nanofluids. J. Appl. Phys. 2011, 110, 104. [CrossRef]

17. Zhou, Y.X.; Wang, Y.S.; Tian, J.H.; Sha, Y.C.; Jiang, X.X.; Gao, S.Y.; Sun, Q.H.; Nie, Q. Breakdown characteristics in transformer oil modified by nanoparticles. High Volt. Eng. 2010, 36, 1155-1159.

18. Kharthik, R.; Raja, T.; Madavan, R. Enhancement of critical characteristics of transformer oil using nanomaterials. Arab. J. Sci. Eng. 2013, 38, 2725-2733. [CrossRef]

19. Lv, Y.Z.; Zhou, Y.; Li, C.R.; Wang, Q.; Qi, B. Recent progress in naofluids based on transformer oil: Preparation and electrical insulation properties. IEEE Electr. Insul. Mag. 2014, 30, 23-32. [CrossRef]

20. Saidur, R.; Leong, K.; Mohammad, H. A review on applications and challenges of nanofluids. Renew. Sustain. Energy Rev. 2011, 15, 1646-1668. [CrossRef]

21. Taha-Tijerina, J.; Narayanan, T.N.; Gao, G.; Rohde, M.; Tsentalovich, D.A.; Pasquali, M.; Ajayan, P.M. Electrically insulating thermal nano-oils using 2D fillers. ACS Nano 2012, 6, 1214-1220. [CrossRef]

22. Wang, Q.; Rafiq, M.; Lv, Y.; Li, C.; Yi, K. Preparation of Three Types of Transformer Oil-Based Nanofluids and Comparative Study on the Effect of Nanoparticle Concentrations on Insulating Property of Transformer Oil. J. Nanotechnol. 2016, 2016, 5802753. [CrossRef]

23. Madavan, R.; SenthilKumar, S.; Willuice Iruthyarajan, M. A comparative investigation on effects of nanoparticles on characteristics of natural esters-based nanofluids. Colloids Surf. A 2018, 556, 30-36.

24. Dhar, P.; Katiyar, A.; Maganti, L.S.; Pattamatta, A.; Das, S.K. Superior dielectric breakdown strength of graphene and carbon nanotube infused nano-fluids. IEEE Trans. Dielectr. Electr. Insul. 2016, 15, 943-956. [CrossRef]

25. Peppas, G.D.; Charalampakos, V.P.; Pyrgieti, E.C.; Bakandritstos, A.; Polykrati, A.D.; Gonos, I.F. A study on the Breakdown Characteristics of Natural Ester Based nanofluids with Magnetic Iron Oxide and $\mathrm{SiO}_{2}$ nanoparticles. In Proceedings of the 2018 International Conference on High Voltage Engineering and Application (ICHVE), Athens, Greece, 10-13 September 2018.

26. Ibrahim, M.; Abd-Elhady, A.; Izzularab, M. Effect of nanoparticles on transformer oil breakdown strength: Experiment and theory. IET Sci. Meas. Technol. 2016, 10, 839-845. [CrossRef]

27. Insulating Liquids_Determination of the Breakdown Voltage at Power Frequency-Test Method; IEC 60156 Ed. 2; IEC: Geneva, Switzerland, 1995.

28. Guide for the Statistical Analysis of Electrical Insulation Breakdown Data; IEEE 62539-2007, EC 62539 Ed.1 (IEEE Std 930 (TM)-2004); IEC: Geneva, Switzerland, 2007.

29. Devins, C.; Rzad, S.; Schwabe, J. Breakdown and pre-breakdown phenomena in liquids. J. Appl. Phys. 1981, 52, 4531-4545. [CrossRef]

30. Beroual, A.; Tobazeon, R. Pre-breakdown phenomena in liquid dielectrics. IEEE Trans. Electr. Insul. 1986, 21, 613-627. [CrossRef]

31. Beroual, A. Electronic and gaseous processes in the pre-breakdown phenomena of dielectric liquids. J. Appl. Phys. 1993, 73, 4528-4533. [CrossRef]

32. Beroual, A.; Zahn, M.; Badent, A.; Kist, K.; Schwabe, A.J.; Yamashita, H.; Yamazawa, K.; Danikas, M.; Chadband, W.D.; Torshin, Y. Propagation and structure of streamers in liquid dielectrics. IEEE Electr. Insul. Mag. 1998, 14, 6-17. [CrossRef]

33. Beroual, A. Pre-breakdown mechanisms in dielectric liquids and predicting models. In Proceedings of the IEEE Electrical Insulation Conference (EIC), Montréal, QC, Canada, 19-22 June 2016.

34. Beroual, A.; Aka, T. Influence of additives and hydrostatic pressure on streamers initiation and dielectric strength of liquids. In Proceedings of the IEEE Annual Report Conference on Electrical Insulation and Dielectric Phenomena (CEIDP), Cancun, Quintana Roo, Mexico, 20-24 October 2002; pp. 248-251.

35. Hwang, J.G.; Zahn, M.; O'sullivan, F.M.; Pettersson, L.A.; Hjortstam, O.; Liu, R. Effects of nanoparticle charging on streamer development in transformer oil-based nanofluids. J. Appl. Phys. 2010, 107, 014310. [CrossRef] 
36. Peppas, G.D.; Charalampakos, V.P.; Pyrgioti, E.C.; Danikas, M.G.; Bakandritsos, A.; Gonos, I.F. Statistical investigation of AC breakdown voltage of nanofluids compared with mineral and natural ester oils. IET Sci. Meas. Technol. 2016, 10,1-9. [CrossRef]

37. Makmud, M.Z.; Illias, H.A.; Chee, C.Y.; Sarjadi, M.S. Influence of conductive and semi-conductive nanoparticles on the dielectric response of natural ester-based nanofluid Insulation. Energies 2018, 11, 333. [CrossRef]

38. Yang, Q.; Yu, F.; Sima, W.; Zahn, M. Space charge inhibition effect of nano- $\mathrm{Fe}_{3} \mathrm{O}_{4}$ on improvement of impulse breakdown voltage of transformer oil based on improved Kerr optic measurements. AIP Adv. 2015, 5, 097207-1. [CrossRef]

39. Sima, W.; Shi, J.; Yang, Q.; Huang, S.; Cao, X. Effects of conductivity and permittivity of nanoparticle on transformer oil insulation performance: Experiment and theory. IEEE Trans. Dielectr. Electr. Insul. 2015, 22, 380-390. [CrossRef]

(C) 2018 by the authors. Licensee MDPI, Basel, Switzerland. This article is an open access article distributed under the terms and conditions of the Creative Commons Attribution (CC BY) license (http:/ / creativecommons.org/licenses/by/4.0/). 